\title{
DEVELOPMENT OF A TRAP FOR FUEL EXHAUST PARTICULATE MATTER UNDER DRIVING CONDITIONS AND GC-MS METHOD FOR THEIR ANALYSIS*1
}

\author{
Dejan Todorović, Zoran Zdravkovski ${ }^{1}$
}

\author{
${ }^{1}$ Institute of Chemistry, Faculty of Natural Sciences and Mathematics, \\ University Ss. Cyril and Methodius, Skopje, Republic of Macedonia \\ zoran@pmf.ukim.mk
}

\begin{abstract}
Simple and useful GC/MS method was developed in order to analyze the toluene soluble components in particulate matter from diesel exhaust. Easily adaptable specially designed trap was built which could be mounted on exhaust pipe of different vehicles. It was filled with different materials on which particles were collected. After collection of the particles, the bare trap and different materials were washed and soaked with toluene. In some cases extraction process was speeded up with ultrasonification of the samples for $30 \mathrm{~min}$. Samples were filtered and concentrated to 125-500 $\mu \mathrm{l}$ and afterwards were directly analyzed by GC/MS. The separated components were identified by Automated Mass Spectral Deconvolution and Identification System (AMDIS) using a specialized user-built library. Five of the identified components [4-methylphenol, 3,3'-dichloro-1,1'-biphenyl, diethyl phthalate, 1,2-benzenedicarboxylic acid, bis(2methylpropyl) ester and mono(2-ethylhexyl) ester of 1,2-benzenedicarboxylic acid] were found in the European priority lists (Category 1 and Category 2) of endocrine disruptors.
\end{abstract}

Key words: vehicle exhaust; diesel motors; particulate trap; GC/MS; endocrine disruptors; European priority list.

\section{КОНСТРУКЦИЈА НА СТАПИЦА ЗА ЧЕСТИЧКИ ОД ИЗДУВНИ ГАСОВИ НА ВОЗИЛА ВО УСЛОВИ НА ВОЗЕЊЕ И НИВНА АНАЛИЗА СО GС-МS}

Разработен е едноставен метод за GC-MS со цел да се анализираат честички растворливи во толуен од издувни гасови на дизел-возила. Конструирана е специјална стапица која може да се прилагоди и монтира на различни возила. Користени се разни материјали на кои честичките се атсорбираат. По собирање на честичките, самата стапица и атсорбентот беа натопени во толуен. Процесот на екстракција може да се забрза ако се изведува во ултразвучна бања во тек од $30 \mathrm{~min}$. Примероците се филтрираат и концентрираат до 125-500 $\mu 1$, а потоа директно се анализираат со GCMS. Издвоените компоненти беа идентификувани со помош на системот за автоматска деконволуција и идентификација на масени спектри. Идентификувани се пет компоненти [4-метилфенол, 3,3'-дихлоро-1,1'-бифенил, диетил фталат, 1,2-бензендикарбоксилна кислеина, бис(2-метилпропил) естер и моно(2-етоксихексил естер на 1,2-бензендикарбоксилна кислеина) од европските приоритетни листи на ендокрини нарушувачи (категорија 1 и категорија 2).

Клучни зборови: издувни гасови; дизел-возила; стапица за честички; ендокрини нарушувачи; GC-MS

${ }^{*}$ Dedicated to Professor Svetomir Hadži Jordanov on the occasion of his $70^{\text {th }}$ birthday. 


\section{INTRODUCTION}

Endocrine disruptors (ED) are exogenous substances that cause adverse health effects in intact human or animal organisms, or their progeny. A wide variety of both man made and naturally occurring chemicals can mimic hormones and thus influence many bodily functions. It has been shown that contaminants can alter hormone production at its endocrine source, the release of stimulatory or inhibitory hormones from adrenal glands like pituitary or hypothalamus, enzymatic biotransformation of hormones, and free hormone concentrations in serum by alteration of concentrations or functioning of proteins transport. The Japanese Environmental Agency in 1998 made a list of 67 chemicals which were labeled as endocrine disruptors. The list includes mostly pesticides and related chemicals, as well as several byproducts of combustion [1-3].

Vehicle exhaust fumes are complex mixtures of gaseous and particulate substances derived from unburned fuel, lubricant oil and combustion products. Their chemical composition is predetermined by the nature of the fuels and mechanical design of the engines. The main components are carbon monoxide $(\mathrm{CO})$, carbon dioxide $\left(\mathrm{CO}_{2}\right)$, nitrogen oxides $\left(\mathrm{NO}_{\mathrm{x}}\right)$, sulfur oxides $\left(\mathrm{SO}_{\mathrm{x}}\right)$, hydrocarbons $(\mathrm{HC})$, as well as particulate matter (PM). The chief constituents of exhaust fumes are elemental carbon as well as polycyclic aromatic hydrocarbons (PAH) along with their methylated, nitrated and oxygenated derivatives and substituted polycyclic aromatic compounds [4, 5]. From an environmental standpoint, the diesel engines, compared to gasoline engines, have an advantage that they emit lower concentrations of "greenhouse gases" such as $\mathrm{CO}$ and $\mathrm{CO}_{2}$. However, their disadvantage is that they emit higher concentration of $\mathrm{NO}_{x}$ and PM. Studies have shown that the compound content varies with particle size. Usually larger particles contain lower mass PAH and vice versa [6]. Sulphur is a key component for one of the nucleation modes that leads to formation of exhaust PM [7]. As a prevention of PM formation, there is a tendency to reduce the sulfur content in the fuels, and presently the maximum allowed amount is $10 \mathrm{ppm}$ $[8,9]$.

These global concerns about adverse health effects and environment concerns lead us to develop a screening method for determination of components in particulate matter from vehicle exhaust. A simple trap, adaptable to any vehicle exhaust pipe, was built in order to collect samples under driving conditions. Herein, we would like to describe the construction of the trap, the optimization of the extraction, gas chromatographic-mass spectrometric (GC-MS) analysis and the initial results from this study.

\section{EXPERIMENTAL PART}

\subsection{Materials and methods}

Toluene (Fluka pestanal and Merck GC quality) was used as solvent for dilution/ extraction of PM [10, 11]. Rotoevaporator model RV 10C S40 (IKA) with the following default toluene programme was applied: bath $60{ }^{\circ} \mathrm{C}$, rotation $-100 \mathrm{rpm}$, vacuum $-77 \mathrm{mBar}$, efficiency $-80 \%$, caloric value $1720 \mathrm{~J} /(\mathrm{kg} \cdot \mathrm{K})$, evaporation enthalpy -427 , density of toluene$867 \mathrm{~kg} / \mathrm{m}^{3}$ was used for the solvent evaporation.

The analysis and identification of the analytes was carried out on an Agilent GCMS model $6890 \mathrm{~N}$ with autosampler coupled to a mass spectrometer 5975B EI/CI. The chromatographic separation was performed on a HP-5MS column, length $30 \mathrm{~m}$, internal diameter $250 \mu \mathrm{m}$ and thickness of the stationary phase of $0.25 \mu \mathrm{m}$. The samples were injected in splitless mode at an injector temperature of $250{ }^{\circ} \mathrm{C}$. The initial column temperature was $40{ }^{\circ} \mathrm{C}$, maintained for $1 \mathrm{~min}$, raised to $300{ }^{\circ} \mathrm{C}$ at a rate of $10{ }^{\circ} \mathrm{C} / \mathrm{min}$, then held at $300{ }^{\circ} \mathrm{C}$ for $3 \mathrm{~min}$. The whole analysis time was $30 \mathrm{~min}$. The temperature of the auxiliary line to the MS was $250{ }^{\circ} \mathrm{C}$, MS quad at $150{ }^{\circ} \mathrm{C}$ and electron ionization was maintained at $230^{\circ} \mathrm{C}$. 
For the purpose of this study various collection materials were tested: filter paper, cotton and glass. The cotton was cleaned in washing machine and air dried. The glass was cleaned with detergent, followed by tap water and deionized water, and dried at $200{ }^{\circ} \mathrm{C}$. Dry filter paper was used. The trap and its parts were cleaned with a detergent, followed by tap water and deionized water. Every part was dried at $150-200{ }^{\circ} \mathrm{C}$ before use. The bolts were cleaned with technical toluene.

After the field test was performed the inner walls of the trap were cleaned with 30-50 $\mathrm{mL}$ of the solvent. Suitable solvent extraction was used for extracting the components.

In some cases, for speeding up the extraction process, ultrasonification was applied for $30 \mathrm{~min}$. The default toluene method on the rotoevaporator was used for solvent reduction. Samples were reduced to $125-500 \mu 1$.

\subsection{Field tests}

The trap was set to be in a coaxial direction to the exhaust system. The distance between the last plane of the exhaust and the first plane of the trap was set to be between $0-2 \mathrm{~cm}$. The chosen route of $34 \mathrm{~km}$ was driven in period of $30-40 \mathrm{~min}$, with average speed of $80-90 \mathrm{~km} / \mathrm{h}$.

\section{RESULTS AND DISCUSSION}

The development of the screening method involved four steps: construction of a trap for collecting the particulate matter, optimizing the extraction procedure, optmizing the chromatographic conditions and mass spectrometric identification of the components.

The trap had to fulfill two major conditions: collect the maximum amount of exhaust particualte matter under driving conditions but at the same time not to interfere with the normal function of the engine. Furthermore, it had to be made of inert material and also adaptable to various vehicles and constructions of the exhaust pipe where it was mounted.
The trap was made from stainless steel, and contains five contact barriers. A scheme of the trap is given Figure 1, and Figure 2 illustrates it mounted on the car exhaust. Trap dimensions are $120 \times 120 \times 100 \mathrm{~mm}$. Four of the contact barriers are fixed and the last one is removable. Fixed contact barriers are with the following dimensions, going from the inlet to the outlet of the trap: $1(60 \times 120 \times 1$ $\mathrm{mm}), 2(60 \times 120 \times 1 \mathrm{~mm}), 3(70 \times 120 \times 1 \mathrm{~mm}), 4$ $(50 \times 120 \times 1 \mathrm{~mm})$. The removable fifth barrier has an opening of $70 \times 90 \mathrm{~mm}$, where glass, filter paper or cotton fabrics were used as fillers of the gap.

The fabric used was made of cotton, the paper was standard quantitative filter paper (Whatman) and the glass was common window glass $(100 \times 80 \times 4 \mathrm{~mm})$.

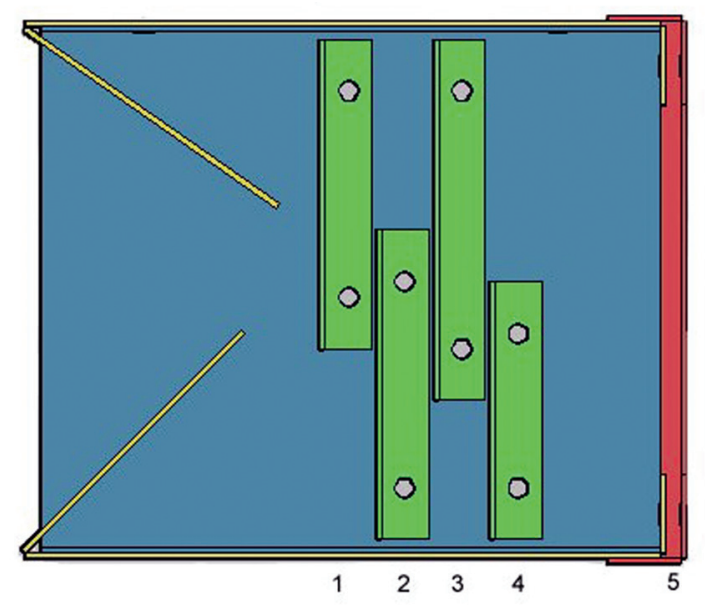

Fig. 1. Construction of the trap used for testing particulate matter (PM)

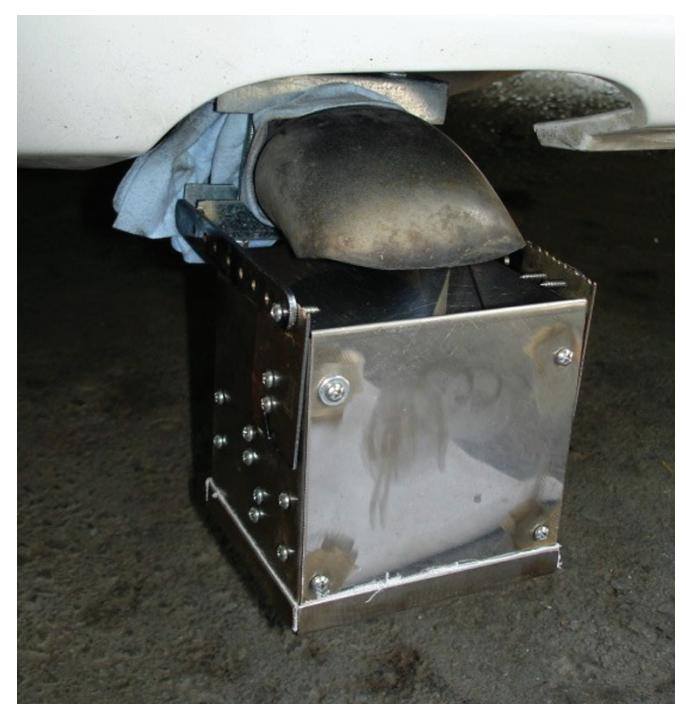

Fig. 2. The trap mounted on the exhaust pipe of a car 
The optimization of the extraction and gas chromatographic conditions was done by modifying published procedures given in the literature $[11,12]$ and the conditions are given in the experimental part.

The identification of the large number of components by their EI mass spectra was performed by the Automated Mass Spectral Deconvolution and Identification System (AMDIS) [13] which has been shown to be very valuable for extraction of the mass spectra of superimposed peaks [14].

AMDIS allows users to build their own libraries so a special library containing 4506 mass spectra was built for the purpose of this study. Since our aim was to cover every possible component we used these starting libraries and their reference number of components: NISTCW (Chemical Weapons) - 62, NISTDRUG (Drugs) - 739, NISTEPA (Environmental Protection Agency) - 1086, NISTFDA (Food and Drug Administration) - 415, NISTFF (Flavors and Fragrances) - 991, NISTTOX (TOXIC) -1213.

An additional mass spectra library with 134 components was also built, using either the AMDIS libraries or the basic NIST library, containing endocrine disruptors. The primary list contained around 180 components and encompasses the endocrine disruptors as given by the European Union and Japan. From the European library only category 1 and category 2 components were utilized. Category 1 includes components which at least one study has provided evidence of endocrine disruption in an intact organism. Category 2 includes components that are potential endocrine disruptors, i.e. in vitro data indicate potential for endocrine disruption in intact organisms. Also, it includes effects in vivo that may, or may not, be ED-mediated and may include structural analyses and metabolic considerations [15]. There is also an available selection of components dependant on the nature of the source of pollution. Japan's list includes 73 components with the nature of components and the nature of the source of the pollution.

The analysis was performed on several diesel vehicles. All were of the common rail construction using high-pressure injection systems from different manufacturers but also of different age and wear using eurodiesel. One gasoline engine was included in this study for comparison to the diesel engines. Multiple runs were performed in order to optimize the extraction and analysis method. The vehicles used for this study, as well as relevant data for each vehicle, are given in Table 1.

$\mathrm{T}$ a b 1 e 1

Model, type, motor capacity, year of manufacture of the vehicles used for testing of particulate matter (PM)

\begin{tabular}{clllll}
\hline \hline Sample & Vehicle & $\begin{array}{c}\text { Motor capacity } \\
/ \mathrm{cm}^{3}\end{array}$ & $\begin{array}{c}\text { Manufactured } \\
\text { /year }\end{array}$ & $\begin{array}{c}\text { Mileage } \\
/ \mathrm{km}\end{array}$ & Fuel \\
\hline 1 & BMW 320 D & 1995 & 2007 & 65000 & Eurodiesel \\
2 & BMW 320 D & & & 180000 & Eurodiesel \\
& $($ E46) & 1951 & 2000 & 121000 & Eurodiesel \\
3 & Citroen Saxo & 1527 & 1999 & & \\
4 & Peugeout 306 & & 192000 & B8 \\
& XND & 1905 & 1998 & & \\
5 & Peugeout 206 & & 289000 & Eurodiesel \\
& SW & 1398 & 2003 & 197000 & Eurodiesel \\
6 & Fiat Fiorino & 1697 & 1996 & 227000 & ES95 \\
\hline \hline
\end{tabular}


The GC-MS analysis on the particulate matter from the exhaust of the tested vehicles followed by a search in the custom-made AMDIS libraries revealed from 1034 to 2785 discreet components. In order to ensure greater accuracy, optimized settings were applied for the deconvolution process: high resolution, high sensitivity, medium peak requirements, and minimum match factor $95 \%$ for component identification [16]. By applying these strict settings, only 53 components, given in Table 2 , were identified. The first five are endocrine disruptors, while the rest are not classified as such by either the European or Japanese standards. Only 4-methylphenol was detected in the particulate matter of both the diesel and gasoline vehicle. It is interesting that in the particulate matter of the vehicle on $\mathrm{B} 8$ there was found only one endocrine disruptor. Despite all precautions, the phthalates are so omnipresent that it cannot be excluded that they have been introduced in the manipulation process. In a work supported by a Japan Automobile Research Institute, 21 endocrine disruptors were investigated in PM. Their study revealed the presence of only two endocrine disruptors (n-pentylphenol and benzo[a]pyrene) from the total list. These components were found both in the diesel and gasoline powered vehicles.

$\mathrm{T}$ a b 1 e 2

Identified components in the exhaust PM

\begin{tabular}{|c|c|c|c|}
\hline No & Sample & CAS & Name \\
\hline & & & Endocrine disruptors \\
\hline 1 & $1,2,3,4,5,10$ & $106-44-5$ & 4-methylphenol \\
\hline 2 & $1,2,3,5,6,7,8,9$ & $2050-67-1$ & 3,3'-dichloro-1,1'-biphenyl \\
\hline 3 & $6,7,8,9$ & $84-66-2$ & diethyl phthalate \\
\hline 4 & $6,7,8,9$ & $84-69-5$ & $\begin{array}{l}\text { 1,2-benzenedicarboxylic acid, bis( } 2 \text {-methyl- } \\
\text { propyl) ester }\end{array}$ \\
\hline \multirow[t]{2}{*}{5} & 6,7 & $4376-20-9$ & $\begin{array}{l}\text { 1,2-benzenedicarboxylic acid, mono(2-ethyl- } \\
\text { hexyl) ester }\end{array}$ \\
\hline & & & Other components \\
\hline 6 & $1,2,4,10$ & $98-82-8$ & (1-methylethyl)benzene \\
\hline 7 & $1,2,3,4,5,10$ & $124-18-5$ & decane \\
\hline 8 & $1,2,3,4,5,10$ & $874-41-9$ & 1-ethyl-2,4-dimethylbenzene \\
\hline 9 & $1,2,3,4,5,9,10$ & $1120-21-4$ & undecane \\
\hline 10 & $1,2,3,4,5,10$ & $527-53-7$ & 1,2,3,5-tetramethyl-benzene \\
\hline 11 & $1,2,3,4,5,10$ & $103-69-5$ & N-ethylbenzenamine \\
\hline 12 & $1-10$ & $112-40-3$ & dodecane \\
\hline 13 & 2,3 & $629-50-5$ & tridecane \\
\hline 14 & 1,2 & $91-57-6$ & 2-methylnaphthalene \\
\hline 15 & $1-10$ & $629-59-4$ & tetradecane \\
\hline 16 & $1,2,3,4,5,10$ & $629-62-9$ & pentadecane \\
\hline 17 & $1-10$ & $544-76-3$ & hexadecane \\
\hline 18 & $1-10$ & $629-78-7$ & heptadecane \\
\hline
\end{tabular}




\begin{tabular}{|c|c|c|c|}
\hline No & Sample & CAS & Name \\
\hline & & & Endocrine disruptors \\
\hline 19 & 2 & $1921-70-6$ & 2,6,10,14-tetramethylpentadecane \\
\hline 20 & 2,5 & $120-51-4$ & benzyl benzoate \\
\hline 21 & $1-10$ & $3622-84-2$ & N-butylbenzenesulfonamide \\
\hline 22 & $1-10$ & $120-12-7$ & anthracene \\
\hline 23 & $1,2,3,5,6,7,9,10$ & $112-95-8$ & eicosane \\
\hline 24 & $2,3,4,5,6,7,9,10$ & $129-00-0$ & pyrene \\
\hline 25 & $1,2,3,4,5,10$ & $629-94-7$ & heneicosane \\
\hline 26 & $1,2,3,4$ & $646-31-1$ & tetracosane \\
\hline 27 & 1,3 & $103-65-1$ & propylbenzene \\
\hline 28 & $1,3,5$ & $108-67-8$ & 1,3,5-trimethylbenzene \\
\hline 29 & $1,3,5,10$ & $138-86-3$ & limonene \\
\hline 30 & $1,7,9$ & $59-89-2$ & 4-nitrosomorpholine \\
\hline 31 & $1,3,4,5,10$ & $535-77-3$ & 1-methyl-3-(1-methylethyl)benzene \\
\hline 32 & 1 & $95-93-2$ & 1,2,4,5-tetramethylbenzene \\
\hline 33 & $1,3,5,10$ & $91-20-3$ & naphthalene \\
\hline 34 & $1,3,4$ & $112-72-1$ & 1-tetradecanol \\
\hline 35 & 3 & $142-62-1$ & hexanoic acid \\
\hline 36 & 3 & $934-74-7$ & 1-ethyl-3,5-dimethylbenzene \\
\hline 37 & 3,4 & $123-08-0$ & 4-hydroxybenzaldehyde \\
\hline 38 & 3,4 & $112-70-9$ & 1-tridecanol \\
\hline 39 & 3 & $630-01-3$ & hexacosane \\
\hline 40 & 3 & $593-49-7$ & heptacosane \\
\hline 41 & 3 & $630-02-4$ & octacosane \\
\hline 42 & 3 & $638-68-6$ & triacontane \\
\hline 43 & $5,6,7,8$ & $111-92-2$ & N-butyl-1-butanamine \\
\hline 44 & 5,10 & $95-50-1$ & 1,2-dichlorobenzene \\
\hline 45 & 5 & $629-73-2$ & 1-hexadecene \\
\hline 46 & 4 & $95-63-6$ & 1,2,4-trimethylbenzene \\
\hline 47 & 4 & $112-92-5$ & 1-octadecanol \\
\hline 48 & 6,9 & $85-01-8$ & phenanthrene \\
\hline 49 & 1 & $111-84-2$ & nonane \\
\hline 50 & 10 & $103-65-1$ & n-propylbenzene \\
\hline 51 & 10 & $108-67-8$ & 1,3,5-trimethylbenzene \\
\hline
\end{tabular}


As expected, all extracts from the emissions particulate matter contained the saturated hydrocarbons. Vehicle 1 uses a diesel particulate filter to capture carbon particles and then intermittently burn them using extra fuel injected directly into the filter, although has a lower amount of particulate matter, the number of components is about the same as in the older types of engines. We can estimate $1.01 \mathrm{mg} \mathrm{PM} /$ $\mathrm{cm}^{2}$, or $2.38 \mathrm{mg} \mathrm{PM} / \mathrm{km}$ driving distance.

The limit of detection was determined on anthracene, as a representative compound of the components identified. The limit of detection was determined to be $0.125 \mathrm{ng} / \mu \mathrm{l}$ which is in the range with literature data [17].

It must be mentioned that the fuels used were from different providers and obtained at different periods. Manufacturers use different batches of mixtures and the variations in the results obtained probably reflect this inconsistency. Emptying the car tanks and using only one batch of diesel fuel unfortunately was not feasible for this study. However, since the purpose was to do a screening of possible endocrine disruptors and other organics, this approach gave us a cross section of the components in the exhaust particulate matter.

Tests were performed on the repeatability of the GC/MS analysis. It was found that the repeatability was acceptable considering the limitations of the mass spectrometer with only \pm 1 out of 36 targets and \pm 15 out of 1880 total number of components. This was attributed to the relatively low scan speed of the quadrupole mass spectrometer which is less than two scans per second. With scanning instruments such as quadrupole MS, a scan is initiated at one point in time. As the scan progresses, time elapses so the last data for the scan is collected at a second point in time. During the scanning process, analyte concentrations change in the source, resulting in skewed spectra. The skew is corrected by averaging spectra across the apex of the chromatographic peak. This significantly complicates the mathematics and accuracy of deconvolution in the case of overlapped spectra.
This drawback is absent in time of flight mass spectrometers [18].

Tests were also performed on the influence of the storage conditions on the collected material. For example, on one of the vehicles (sample 1) two valid tests were performed, the difference being the storage time of the collected material. One was performed immediately, while the other was kept at room temperature more than $12 \mathrm{~h}$. It was interesting that in the latter case the number of components was 2289,18 more than in the one that was analyzed immediately. In another instance (sample 2), the collected material was kept at a temperature of $-18{ }^{\circ} \mathrm{C}$, and the results showed an increase in the number of components from 1816 to 1826 . This can also be explained by the low number of data points in the mass spectra. However, all other GC analyses were performed immediately after the extraction of the particulate matter.

\section{CONCLUSION}

Convenient method for collection of fuel exhaust particulate matter utilizing specially designed trap was developed. A GC/MS method was developed for screening analysis of components in fuel exhaust particulate matter. The method is inexpensive, easily applicable and suitable for primary information of the identified components which can lead to further studies. It can be conveniently employed for routine qualitative analysis in any working and testing conditions. Identification of five endocrine disruptors can lead to further development of this method for quantitative analysis. Furthermore, these results revealed that PM from diesel and gasoline vehicles must be investigated in greater details.

\section{REFERENCES}

[1] Murahashi, T. Sasaki, S. Nakajima, T. Determination of endocrine disruptors in automobile exhaust particulate matter, J. Health Science, 49 (2003), 72-75. 
[2] Guillette L. J., Gunderson M. P, Alterations in development of reproductive and endocrine systems of wildlife populations exposed to endocrinedisrupting contaminants. Reproduction, 122 (2001), 857-864.

[3] Japan Environmental Agency, Strategic Programs on Environmental Endocrine Disruptors '98, Japan Environmental Agency, Tokyo, 1998. www.env.go.jp/ en/chemi/ed/bda_speed98.pdf, accessed November, 2010.

[4] Ono-Ogasawara, M. Smith, T. J., Diesel exhaust particles in the work environment and their analysis, Ind. Health, 42 (2004), 389-399.

[5] Mostert, M. M. R., Levels of Pollutans on the surface of children playgrounds situated in public parks, Doctoral thesis, Faculty of Science, Queensland Univeristy of Technology, Brisbane, 2008, eprints. qut.edu.au/19202/1/Maria_Mostert_Thesis.pdf, accessed November 2010.

[6] Suro, J., Chen, Q., Kennedy, I. M., Cahill, T. A., Kelly, P. B., Characterization of chemical composition and size of diesel exhaust particulate matter by LDITOF/ MS, Symposium on Chemistry of Liquid and Gaseous Fuels, San Francisco, Prepr. Pap.-Am. Chem. Soc., Div. Fuel Chem., 45, 294-298 (2000). www.anl. gov/PCS/acsfuel/preprint $\% 20$ archive/Files/45_2_ SAN\%20FRANCISCO_03-00_0294.pdf, accessed November 2010.

[7] Dobbins, R. A., Hydrocarbon Nanoparticles Formed in Flames and Diesel Engines, Aerosol Sci. and Tech., 41 (2007), 485-496.

[8] EN590:2009(E) Automotive fuels - Diesel - Requirements and test methods, European committe for standardization (CEN), Management centre: Avenue Marnix 17, B-1000 Brussels Belgium, April 2009.

[9] BS228:2008(E) Automotive fuels - Unleaded petrol - Requirements and test methods gasoline specification standard, European Committe for standardization (CEN), Management centre: Rue de Stassart 36, B-1050 Brussels, Belgium, July 2008.

[10] 10. Abul-Milh, M., Westberg, H., Bergvall, C., Elfver, L., Westerholm, R., Quantification and identification of particle associated polycyclic aromatic hydrocarbons (PAH) in exhaust emissions from diesel engines, EMFO project, June 2007.

[11] Stauffer, E., Dolan, J. A., Newman, R., Fire debris analysis, Elsevier Inc., USA, 2008.

[12] Bergvall, C., Elfver, L., Westerholm, R., Evaluation of accelerated solvent extraction of deuterated benzo(a) pyrene and dibenzo(a,i)pyrene from diesel standard reference material 2975, The 21st International Symposium for Polycyclic Aromatic Hydrocarbons (ISPAC 2007), 2007. www.pff.nu/upload/EMFO/ resultat/Delprogram_3_4/Bilaga\%206.pdf, accessed November 2010.

[13] Stein, S. E., An integrated method for spectrum extraction and compound identification from GC/MS data, NIST, Gaithersburg, Maryland, USA, 1999, chemdata.nist.gov/mass-spc/amdis/docs/method. pdf, accessed March 2011.

[14] Meng, C.-K., Szelewski, M., Can “deconvolution” improve GC/MS detectability? Agilent Technologies Inc.,Wilmington, USA, 2010, accessed November 2010 .

[15] Endocrine disruptors: Study on gathering information on 435 substances with insufficient data, RPS BKH Consultants B.V., Netherlands, 2002.ec.europa.eu/ environment/endocrine/documents/bkh_report.pdf, accessed November 2010.

[16] Stein, S. E., Scott, D. R., Optimization and testing of mass spectral library search algorithms for compound identification, NIST, J. Am. Soc. Mass Spec., 5 (1994), 859-866.

[17] Marjanović, N. J., Kravić, S. Ž., Suturović, Z. J., Švarc-Gajić, J. V., Determination of sensitivity limit in quantative analysis of polycyclic aromatic hydrocarbons by GC-MS, Acta Per.Technol., 35 (2004), 111-119. http://www.doiserbia.nb.rs/img/ doi/1450-7188/2004/1450-71880435111M.pdf.

[18] Binkley, J., Libarondi, M., Comparing the Capabilities of Time-of-Flight and Quadrupole Mass Spectrometers, Spectroscopy, Sol. Mat. Anal., July, 2010, http://spectroscopyonline.findanalytichem. com/spectroscopy/article/articleDetail.jsp?id=677 $324 \&$ sk $=\&$ date $=\&$ pageID $=2$, accessed November 2010 . 